\title{
How reliable are your design inputs?
}

\author{
MJ Dunn Evolution Mining Ltd, Australia
}

\begin{abstract}
A variety of methods are used in underground design, including empirical, observational, analytical and numerical modelling. All design methods require inputs, and these are based on data obtained from core logging, mapping, laboratory testing, field observations and monitoring. This data then has to be compiled and interpreted so that meaningful and reliable design inputs can be derived.

Design inputs are required to a have reliability and confidence level that is commensurate with the level of design (scoping through to operational) and that will ultimately satisfy the design reliability and acceptable risk profile for the design. To obtain reliable design inputs, data of sufficient quantity and quality has to be collected and analysed. The variability of this data has to be understood so that reliable inputs can be derived.
\end{abstract}

Currently, very little quantitative guidance exists in the literature on assessing the reliability and confidence of geotechnical studies and design, although there have been attempts by various authors (Haile 2004; Haines et al. 2006; Read \& Stacey 2009; Dunn et al. 2011) to qualitatively describe what level of geotechnical data is required. Recently, a number of authors have outlined methods that could be applied to assess the reliability of geotechnical data.

These methods have been discussed, and the application of some methods has been demonstrated on data from underground feasibility studies to assess the reliability of design inputs. A preliminary rating scheme to assess the reliability of geotechnical models and design inputs has been proposed.

\section{Introduction}

It is generally accepted that underground mine designs should have a confidence level that is commensurate with the project's position within the project lifecycle. The project lifecycle covers the scoping, pre-feasibility, feasibility, final design, construction and closure stages. A key component to defining the confidence level of the underground mine design is the confidence and reliability of the design input parameters. In mining geotechnical engineering, the development of reliable input parameters can be challenging and, more often than not, it is difficult to assess the level of reliability. This paper attempts to outline some of the issues associated with developing reliable design input parameters.

\section{$2 \quad$ Underground mine design}

In geotechnical engineering, a variety of design methods are used for underground mine design. These can broadly be classed as empirical, observational, analytical and numerical methods, and they are briefly described in this paper. Irrespective of what design method is used and whether the design approach is deterministic or probabilistic, the reliability of the design is largely influenced by the reliability of input parameters.

\subsection{Empirical methods}

These include various rock mass classification systems such as the Q-system (Barton et al. 1974) and Bieniawski's $(1976 ; 1989)$ rock mass rating $(\mathrm{RMR})$, which are used both to classify the rock mass as well as for ground support design and excavation design. 
Laubscher's (1990) mining rock mass rating (MRMR) is widely used in cave mining designs, whilst the modified stability graph method (Mathews et al. 1981; Potvin 1988) is widely used in open stope design. There are a number of empirically derived pillar design formulae (Hedley \& Grant 1972; Lunder \& Pakalnis 1997), as well as Carter's (2000) scaled span method, for crown pillar design.

The empirically derived Hoek and Brown failure criterion (Hoek \& Brown 1988) and geological strength index (GSI) (Hoek \& Marinos 2000) are widely used to develop rock mass strength parameters.

The above are just some examples of various empirical systems used in underground mine design. It is worthwhile noting that some of these systems are used to classify the rock mass as well as to develop design inputs and, in some cases, are used as a design method.

\subsection{Observational methods}

These include the observational design approach, as outlined by Terzaghi (Peck 1969), and systems such as the New Austrian Tunnelling Method (NATM) and observational cable bolt design (Hutchinson \& Flamagne 2000).

\subsection{Analytical methods}

These include a variety of closed-form solutions such as the Kirsch equations, beam theory (Beer \& Meek 1982), key-block methods (Goodman \& Shi 1985) etc.

\subsection{Numerical methods}

Numerical methods range from simple two-dimensional elastic boundary element analyses to more complicated two-dimensional analyses using tools such as Phase 2, FLAC and UDEC. Three-dimensional (3D) analyses range from boundary element analyses using codes such as Map3D (Wiles 2015) to more complicated non-linear finite element (e.g. Abaqus), finite difference (e.g. FLAC3D) and distinct element methods (e.g. 3DEC).

\section{$3 \quad$ Project lifecycle and design requirements}

\subsection{General requirements}

As a project progresses through the project lifecycle, there is an increasing level of technical and economic knowledge gained. This is also a requirement for the reporting of mineral resources and reserves. Geotechnical data and design fall under the modifying factors for the Joint Ore Reserves Committee (JORC) (2012), which requires that the confidence of the modifying factors be considered in the conversion of mineral resources to ore reserves. It is required that at least a pre-feasibility study should be undertaken to support the conversion of mineral resources to ore reserves. Typically, a feasibility study would have a higher level of confidence than a pre-feasibility and, hence, confidence of the modifying factors would be higher.

Figure 1 shows the typical accuracy required for costing various stages in a project lifecycle, and these range from $30-35 \%$ for scoping studies to $10-15 \%$ for final feasibility studies. These accuracy ranges infer that there is an increasing improvement in the design and that uncertainty has been reduced.

\subsection{Geotechnical requirements}

In mining geotechnical engineering, it is often difficult to relate the confidence of the geotechnical design to the cost accuracy typically required, or to the reporting of mineral resources and reserves. Various authors have attempted to provide guidance on the required confidence of geotechnical models.

Steffen (1997) linked slope angles and the degree of design confidence based on the uncertainty of the underlying geotechnical data to the resource-reserve process, and proposed the classification shown in 
Table 1. Whilst the Steffen (1997) paper focused on open pit mines, the concepts covered in the paper are also applicable to underground mines.

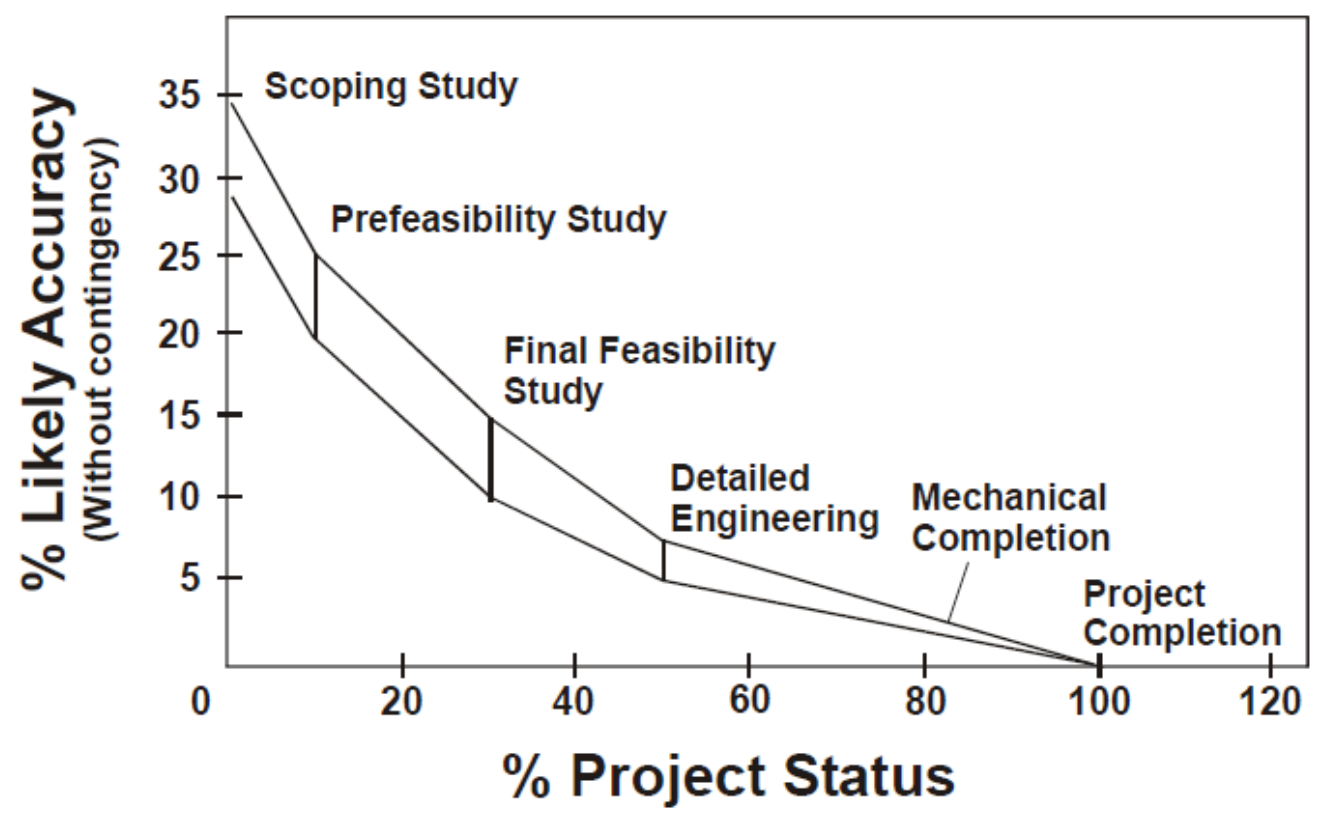

Figure 1 Probable accuracy of each study/design phase (McCarthy 1993)

Table 1 Geotechnical confidence classifications proposed by Steffen (1997)

\begin{tabular}{|c|c|}
\hline Category & Description \\
\hline 1 - Proven slope angles & $\begin{array}{l}\text { Geotechnical investigations carried out to a feasibility study standard. In } \\
\text { essence designs should have a minimum confidence level of } 85 \% \text { requiring: } \\
\text { - Continuity of stratigraphy and lithological units confirmed in space } \\
\text { through adequate intersections. } \\
\text { - Detailed structural mapping of rock fabric is implied. } \\
\text { - Strength characteristics of structural features and the rock mass } \\
\text { - through appropriate testing. }\end{array}$ \\
\hline 2 - Probable slope angles & $\begin{array}{l}\text { Equates to a design based on information that allows the following: } \\
\text { - Reasonable assumptions on continuity of stratigraphy and } \\
\text { lithological units. } \\
\text { - Some structural mapping has been carried out and all major } \\
\text { - features and joint sets should be identified. } \\
\text { - Limited rock testing for physical properties of the in situ rock and } \\
\text { - Preliminary groundwater analysis. } \\
\text { - Enough information to conduct simplified design models with } \\
\text { sensitivities. }\end{array}$ \\
\hline 3 - Possible slope angles & $\begin{array}{l}\text { Equates to an inferred design using limited geotechnical investigations. } \\
\text { Typical slope angles will be based on experience verified with rock mass } \\
\text { ratings and some inference to geological conditions within the affected rock } \\
\text { mass. }\end{array}$ \\
\hline
\end{tabular}


Haile (2004) proposed a framework for classifying geotechnical models based on the structure of resource-reserve reporting codes. To avoid confusion with resource and reserve classifications, the terms 'implied', 'qualified', 'justified' and 'verified' were introduced and are described as follows:

- Implied: with a low level of reliability, with only global estimates of geotechnical characteristics being available.

- Qualified: geotechnical model has a reasonable level of confidence.

- Justified: with a high level of confidence in the intrinsic spatial variability of geotechnical characteristics.

- Verified: based on in situ knowledge of the rock mass, which provides a reliable model of the intrinsic variability of geotechnical characteristics.

Table 2 outlines the general requirements for a geotechnical model. Haile (2004) also provided qualitative guidance, relating the geotechnical data requirements to the mining method and orebody geometry, for different project stages. This approach factors in the geotechnical risk associated with different mining methods and orebodies (e.g. a wide shallow pit versus a deep narrow pit).

Table 2 Geotechnical classification of mining projects (Haile 2004)

\begin{tabular}{|c|c|}
\hline Data type & Requirements \\
\hline \multirow[t]{3}{*}{ Implied (inferred) } & $\begin{array}{l}\text { Geotechnical model has a low level of reliability and is based on global estimates } \\
\text { of geotechnical characteristics. }\end{array}$ \\
\hline & $\begin{array}{l}\text { Will enable only a limited scope of analysis, and development of only conceptual } \\
\text { level, mine-wide design parameters. }\end{array}$ \\
\hline & $\begin{array}{l}\text { Variability or uncertainty in the geotechnical model could have a significant } \\
\text { impact on the economic viability of the project. }\end{array}$ \\
\hline \multirow[t]{3}{*}{ Qualified (indicated) } & $\begin{array}{l}\text { Geotechnical model has a reasonable level of confidence and provides a broad } \\
\text { indication of the intrinsic spatial variability of the geotechnical characteristics. }\end{array}$ \\
\hline & $\begin{array}{l}\text { A reasonable scope of analysis could be applied, which broadly defines } \\
\text { geotechnical domains, enabling the development of reasonably reliable, } \\
\text { domain-specific design parameters. }\end{array}$ \\
\hline & $\begin{array}{l}\text { Variability or uncertainty in the geotechnical model could have a moderate } \\
\text { impact on the economic viability of the project. }\end{array}$ \\
\hline \multirow[t]{3}{*}{ Justified (measured) } & $\begin{array}{l}\text { Geotechnical model has a high level of confidence and provides a good } \\
\text { indication in the intrinsic spatial variability of the geotechnical characteristics. }\end{array}$ \\
\hline & $\begin{array}{l}\text { A comprehensive scope of analysis could be applied to well-defined } \\
\text { geotechnical domains enabling the development of domain-specific mine design } \\
\text { parameters. }\end{array}$ \\
\hline & $\begin{array}{l}\text { Variability or uncertainty in the geotechnical model would not significantly } \\
\text { affect the economic viability of the project. }\end{array}$ \\
\hline \multirow[t]{2}{*}{ Verified } & $\begin{array}{l}\text { Geotechnical model is based on in situ knowledge of the rock mass and provides } \\
\text { a reliable model of the intrinsic variability of geotechnical characteristics. } \\
\text { Performance of the recommended design parameters have been verified } \\
\text { through historical experience from neighbouring excavations and/or interim pit } \\
\text { slopes. }\end{array}$ \\
\hline & $\begin{array}{l}\text { The design has been demonstrated to be practical and achievable. Variability or } \\
\text { uncertainty in the geotechnical model would not adversely affect either the } \\
\text { operational or economic viability of the project. }\end{array}$ \\
\hline
\end{tabular}


Read and Stacey (2009) provide guidance on target confidence levels required for geotechnical models necessary for large open pit slope design for different project stages. They consider conceptual (Level 1); pre-feasibility (Level 2); feasibility (Level 3); design and construction (Level 4); and operations (Level 5). These are shown in Table 3. Descriptive guidelines for estimating the level of confidence in the data for each model component at each level of development are also provided. For consistency with the reporting of exploration results, mineral resources and reserves, the guidelines were purposely matched with the descriptive framework used by the 2004 Australian JORC code (Joint Ore Reserves Committee 2004). The JORC code was updated in 2012.

Table 3 Suggested target levels of data confidence by project stage (after Read \& Stacey 2009)

\begin{tabular}{|c|c|c|c|c|c|}
\hline \multicolumn{6}{|c|}{ Project stage } \\
\hline $\begin{array}{l}\text { Project level } \\
\text { status }\end{array}$ & Conceptual & Pre-feasibility & Feasibility & $\begin{array}{l}\text { Design and } \\
\text { construction }\end{array}$ & Operations \\
\hline $\begin{array}{l}\text { Geotechnical } \\
\text { level status }\end{array}$ & Level 1 & Level 2 & Level 3 & Level 4 & Level 5 \\
\hline $\begin{array}{l}\text { Geotechnical } \\
\text { characterisation }\end{array}$ & $\begin{array}{l}\text { Pertinent } \\
\text { regional } \\
\text { information }\end{array}$ & $\begin{array}{l}\text { Assessment and } \\
\text { compilation of } \\
\text { initial mine scale } \\
\text { geotechnical } \\
\text { data }\end{array}$ & $\begin{array}{l}\text { Ongoing } \\
\text { assessment and } \\
\text { compilation of } \\
\text { all new mine } \\
\text { scale } \\
\text { geotechnical } \\
\text { data }\end{array}$ & $\begin{array}{l}\text { Refinement of } \\
\text { geotechnical } \\
\text { database and 3D } \\
\text { model }\end{array}$ & $\begin{array}{l}\text { Ongoing } \\
\text { maintenance of } \\
\text { geotechnical } \\
\text { database and 3D } \\
\text { model }\end{array}$ \\
\hline \multicolumn{6}{|c|}{ Target levels of data confidence for each model } \\
\hline Geology & $>50 \%$ & $50-70 \%$ & $65-85 \%$ & $80-90 \%$ & $>90 \%$ \\
\hline Structural & $>20 \%$ & $40-50 \%$ & $45-70 \%$ & $60-75 \%$ & $>75 \%$ \\
\hline Hydrogeological & $>20 \%$ & $30-50 \%$ & $40-65 \%$ & $60-75 \%$ & $>75 \%$ \\
\hline Rock mass & $>30 \%$ & $40-65 \%$ & $60-75 \%$ & $70-80 \%$ & $>80 \%$ \\
\hline Geotechnical & $>30 \%$ & $40-60 \%$ & $50-75 \%$ & $65-85 \%$ & $>80 \%$ \\
\hline
\end{tabular}

Cepuritis and Villaescusa (2012) outline the data and design reliability required for open stope span design, as well as what design methods should be applied for different project stages. The suggested reliabilities are similar to that proposed by Read and Stacey (2009) and are as follows:

- Conceptual:

- Pre-feasibility:

- Feasibility:

- Initial construction:

- Early to mid-life operations:

- Mature operations:
$<50 \%$

$50-60 \%$

$60-70 \%$

$70 \%$

$80 \%$

$85 \%$

The guidelines provided by Steffen (1997), Haile (2004), Read and Stacey (2009) and Cepuritis and Villaescusa (2012) are useful, but are essentially qualitative in nature and are subjective, often requiring considerable engineering judgment in their application. Several authors (Read \& Stacey 2009; Cepuritis \& Villaescusa 2012) have attempted to allocate numerical values to the required confidence levels; however, no guidance is provided on how these confidence levels should be calculated or estimated. 
Most of the guidelines have been developed in the context of open pit slope design; however, they can be applied to underground mine design.

\section{$4 \quad$ Developing reliable inputs}

\subsection{Confidence and reliability}

The terms 'confidence' and 'reliability' are often used interchangeably when discussing geotechnical data and models, which can be confusing.

Confidence can be expressed as a level or an interval. A confidence level refers to the percentage of all possible samples that can be expected to include the true population parameter. Statisticians use a confidence level to describe uncertainty associated with the interval estimate.

A confidence interval is used to express the degree of uncertainty associated with a sample statistic. A confidence interval is an interval estimate combined with a probability statement. Confidence intervals are preferred to point estimates and to interval estimates, because only confidence intervals indicate (a) the precision of the estimate and (b) the uncertainty of the estimate.

Reliability is a statement of error or precision of an estimate. Data reliability is a state that exists when data is sufficiently complete and error free to be convincing for its purpose and context.

\subsection{Geotechnical model and design inputs}

Design inputs are derived for the geotechnical model either as specific values such as rock mass strength parameters or as spatial models representing geological unit boundaries or major structures. Hence, the reliability of inputs is directly related to the reliability of the geotechnical model and the underlying data. The geotechnical model is made up of several components, as described in Read and Stacey (2009), and these are summarised in Table 4.

Table 4 Overview of geotechnical model components

\begin{tabular}{ll}
\hline Component & Description \\
\hline Geological model & $\begin{array}{l}\text { The geological model generally consists of the lithology, alteration, } \\
\text { weathering, mineralised zones and the in situ stress state. The } \\
\text { reliability of boundaries between zones is a key issue. }\end{array}$ \\
\hline Structural model & $\begin{array}{l}\text { Consists of the major structures (large faults, bedding and folds) and } \\
\text { minor structures or fabric (joints and minor faults). } \\
\text { The reliability of the location of major structures is a key issue as these } \\
\text { often play a significant role in controlling instability. }\end{array}$ \\
\hline Hydrogeological model & $\begin{array}{l}\text { The hydrogeological model consists of hydrogeological units, hydraulic } \\
\text { conductivities, flow regimes, phreatic surfaces and the pore pressure } \\
\text { distribution, and water quality distribution. }\end{array}$ \\
\hline Rock mass model & $\begin{array}{l}\text { The rock mass model consists of the intact rock strength, defect shear } \\
\text { strength, rock mass strength and rock mass classification. These are } \\
\text { used to determine the input parameters for geotechnical analyses thus } \\
\text { having an understanding of their variability and reliability is a key issue. } \\
\text { Geotechnical or geomechanical domains that exhibit similar rock mass } \\
\text { and structural characteristics. Geotechnical domains form the basis of } \\
\text { geotechnical design sectors or areas. }\end{array}$ \\
\hline Geotechnical domains &
\end{tabular}




\subsection{Requirements for developing reliable geotechnical models}

The geotechnical model and its various underlying components are based on different types of data at different confidence levels and reliability; thus, quantifying the reliability of a geotechnical model is fraught with difficulties. A number of key factors that influence the data reliability and, hence, the geotechnical model are briefly discussed in this paper.

\subsubsection{Data uncertainty}

The term 'uncertainty' is loosely applied in geotechnical engineering. McMahon (1985) outlined six types of uncertainty encountered in geotechnical engineering, and these are broadly divided into natural uncertainty and uncertainty related to human nature. Baecher and Christian (2003) provide a similar division and distinguish between uncertainty related to natural variations in time and space (randomness) and uncertainty related to lack of understanding or knowledge. These are referred to as aleatory and epistemic uncertainly respectively by Kiuregihain and Ditevsen (2009, cited in Hadjigeorgiou \& Harrison 2011).

When developing a geotechnical model, various uncertainties need to be considered in the context of the project lifecycle and the required level of confidence and reliability. The following questions need to be addressed in an attempt to minimise uncertainty (Dunn 2014):

- Is there sufficient data to capture natural variations in the rock mass?

- Is the spread of the data sufficient to adequately define boundaries between different rock units and identify critical structures or zones that could be problematic?

- Is the data collection consistent using industry accepted practices?

- How good is the quality of data collection and what quality assurance and quality control processes are used?

- Is there a bias in the data such as direction of drilling, or sampling of stronger materials?

- How good is the laboratory testing programme, both in quantity and quality of testing?

- How is the data managed?

- How good is the data interpretation?

\subsubsection{Data sufficiency}

The question of how much data is needed regularly arises during geotechnical design studies. Dunn (2014) provided an overview of some published guidelines, and these will not be repeated in this paper. The available guidelines include the following:

- Department of Industry and Resources geotechnical considerations guideline for underground mines, published in 1997 (Department of Industry and Resources 1997). This document suggests that the appropriate geotechnical data are collected from a representative number of cored boreholes.

- Haines et al. (2006) considered geotechnical data in terms of geotechnical risks and the need to reduce risk by having a better understanding of the geotechnical environment. A summary of their experience of geotechnical drilling and logging conducted for various studies, from scoping through to feasibility level, expressed as a proportion of resource holes drilled is provided. Generally, there is a doubling in the percentage of geotechnical holes as the study progresses.

- Dunn et al. (2011) suggested an approach based on progressively gathering data in line with the resource-reserve reporting process. By linking the geotechnical data collection programme to the resource drilling programme and ensuring that a representative proportion of cored holes are 
geotechnically logged to an appropriate level, it is possible to increase the level of geotechnical data available in the early stages of a mining project.

Unfortunately, geotechnical data collection programmes are often limited by the resources available or by access. The design engineer can either motivate for additional resources (not always successful) or can attempt to focus the existing resources on what are considered the most critical components.

\subsubsection{Data quality}

Hadjigeorgiou and Harrison (2011) outline sources of error associated with data collection and testing programmes, which ultimately result in uncertainty. Data collection is a critical step in the minimisation of uncertainty and includes field data collection and laboratory testing programmes. A comprehensive and well-designed field data collection programme is critical in reducing uncertainty.

Hadjigeorgiou (2012) provides a good overview of shortcomings in data collection and how data can be more effectively used in solving geotechnical problems. Dunn (2013) outlines a number of guidelines to minimise input data uncertainty:

- Understand what data is needed and the goals of the programme.

- Use well-defined data collection procedures and staff who have been adequately trained in standard geotechnical techniques.

- Implement data collection quality control procedures.

- Implement sound sampling procedures and use accepted testing procedures (International Society for Rock Mechanics (ISRM), ASTM) and certified laboratories for material testing.

- Use statistical methods to define minimum number of samples required for each material.

- Develop statistical descriptions for all parameters used including indicators of variation (histograms are particularly useful for understanding data distributions).

- Ensure that data is stored in well-constructed and managed databases.

- Make use of visualisation tools to view data in three dimensions and gain a better understanding of the spatial distribution of data.

\subsubsection{Data interpretation}

Data interpretation is a critical task in the development of the various components that make up the geotechnical model. Data interpretation is often subjective and can be broken up into two categories: first, where judgement and experience play a major role and is generally qualitative; second, where statistical tools can be used to quantify certain parameters.

The delineation of lithology, mineralisation, alteration and weathering boundaries, and major structures is reliant on the number of intersections (drill hole or mapping) and the quality of interpretation by the geologist. Visualisation, modelling and interpolation tools are available to assist in this process. However, there is still a significant reliance on the competent professional. This largely falls into the first category of interpretation.

For the hydrogeological model, data needs to be interpreted in the context of the geological and structural models and, if either of these has a low confidence, then it is likely that the confidence of the hydrogeological model will be negatively influenced. In underground mine design, water quality and the potential for corroding of ground support is important.

For the development of the rock mass model, data from a number of sources needs to be collated and interpreted. Laboratory test results need to be scrutinised to ensure that they are valid tests and that they have been correctly interpreted. Geotechnical logs need to be reviewed and collated for both rock mass and rock fabric data. The use of histograms, cumulative distributions and descriptive statistics are useful 
tools for interpreting laboratory and logging data. Statistical tests to evaluate differences in data, and whether data subsets can be combined, should be undertaken. The visualisation and interrogation of geotechnical data in three dimensions is extremely useful in the interpretation of rock mass and laboratory testing data. Typically, the interpretation of rock mass data relies on both qualitative and quantitative methods.

\section{$5 \quad$ Assessing input reliability}

Assessing the reliability of geotechnical models and design input parameters relies on application of sound engineering judgement and various tools. In order to assess the reliability it is necessary to understand the uncertainty associated with the geotechnical model. This requires an understanding of natural variability, as well the variability associated with data collection and the interpretation of that data used in developing the geotechnical model.

\section{$5.1 \quad$ Spatial models}

The development of spatial models, which reflect the geological units, boundaries and major structures, is largely dependent on the density and spatial distribution of the data used to develop the model. There is a link to the data used for the resource model, but this is typically focused on the orebody and immediate surrounds. Therefore, the geological and structural reliability tends to decrease away from the orebody.

The number of mapping points or drill hole intercepts, the location of these points, and the quality of the data collected at these points, all influence the interpretation. The implementation of quality control procedures is required to ensure that the survey is correct and that the data quality is satisfactory and will not compromise the interpretation and development of the model.

There is a range of sophisticated tools for the modelling of geology and structures, but the reliability of the model is largely dependent on the experience and judgement of the professional developing the model. For this reason, it is imperative that the models and input data be independently reviewed and verified.

Geotechnical block models are becoming more common place in the industry, and these are also largely dependent on the density and spatial distribution of the data used to develop models. In addition, there are several modelling parameters that can have a dramatic influence on the quality of the block model. Again, the reliability of the geotechnical block model is largely dependent on the experience and judgement of the professional developing the model, and should also be subject to independent review and verification.

\subsection{Parameter models}

In the case of parameter models, there is generally some sort of measurement or description (e.g. rock mass characteristics, field testing, laboratory testing, orientation measurement etc.) to which various statistical methods could be applied when assessing the reliability. The reliability of the data density and spatial distribution is largely dependent on the experience and judgement of the professional developing the model. This section will focus on some of the tools that can be applied to improve and assess the reliability of input parameters.

\subsubsection{Combining data sets}

There is sometimes insufficient data to make a reliable estimate of the rock mass properties, and it is desirable to increase the data set by including data from nearby deposits or from other studies, thereby increasing the reliability. This can only be done if the design engineer can demonstrate that the data are from the same population.

Thomas (2013) provided an overview of various statistical tests that could be used to assess the similarities in properties between data sets from different areas, and this will not be repeated in the this paper. These 
methods can be applied to assess whether data can be combined, or to assess if there are real differences between data sets or areas. This is potentially a useful tool to assist in defining geotechnical domains.

\subsubsection{Sampling requirements}

Laboratory testing of various types is an important component of the determination of input parameters. The question of how many tests are required is often asked. Often the number of tests undertaken is governed by budget constraints, or the minimum of five tests for the ISRM suggested methods is applied. When undertaking laboratory testing it is also necessary to consider that not all tests will be valid, and provision should be made for additional testing to ensure a minimum number of valid tests results is achieved. Given the natural variability of rocks, the testing requirements could vary from rock type to rock type. Small sampling theory can be applied to estimate how many samples are required to obtain a reliable estimate (Gill et al. 2005).

Fillion and Hadjigeorgiou (2013) explored how small-sampling theory could be applied to assessing the results of laboratory testing from an operating mine, and this will not be repeated in this paper. They showed that even if the number of specimens tested is higher than the minimum proposed by the ISRM suggested methods, the sample size was too small to obtain reliable strength values for most of the rock domains. It was also discovered that the minimum sample size obtained using the confidence interval approach is significantly influenced by the test results sequence used for the analyses. This can arise when samples from a relatively small zone are tested, resulting in misleading statistics. This highlights the need to have a reasonable spatial distribution of testing data so that the material variation is captured.

\subsubsection{Parameter uncertainty}

Read (2013) outlined two methods that could be used for assessing parameter uncertainty. The first is the coefficient of variation $\left(C_{v}\right)$, which is determined from the mean and standard deviation (SD) of a data set and is expressed as a percentage. Typically, a $C_{v}$ value of less than $10 \%$ is considered low and values greater than $30 \%$ are considered high. Wiles (2006) demonstrated how the $C_{v}$ could be used in assessing the reliability of numerical modelling predictions.

Read (2013) concluded that whilst $C_{v}$ is a valuable screening mechanism when making decisions about the level of confidence in a selected design parameter; however, it is subjective and does not provide a numerical measure of the reliability of the data. Read (2013) suggested a second approach to overcome this difficulty, based on a modified Bayesian approach (Harr 1996), to estimate the expected value of the reliability of a dataset. The method uses a simple spreadsheet format and can be applied to any set of geotechnical data. It is particularly useful for evaluating laboratory testing data. This method supplements the more common approach of using the mean, standard deviation and median for assigning design input values. There would also be value in applying this approach to data sets for different study stages to assess whether the data reliability improves as the project progresses.

Table 5 summarises uniaxial compressive strength (UCS) data from a feasibility study and includes the 25th, 50th and 75th percentiles $\left(P_{25}, P_{50}\right.$ and $\left.P_{75}\right)$ as well as the expected reliability $(E[R])$ at the mean and $P_{25}$ values using the modified Bayesian approach (Harr 1996). For the metasediment and ore rock units, the UCS statistics incudes the complete database as well as a data set where low (unreliable) UCS values were excluded. It is noted that excluding unreliable values improves the $C_{v}$, but does not necessarily improve the $E[R]$. In this example, using the mean value does not satisfy a reliability of $60-75 \%$ required for a feasibility study, but using a $\mathrm{P}_{25}$ value does. 
Table 5 Summary of UCS (MPa) data from an underground mine feasibility study

\begin{tabular}{lccccccccc}
\hline Rock unit & Count & Mean & SD & $\mathbf{C}_{\mathrm{v}}(\%)$ & $\mathbf{P}_{25}$ & $\mathbf{P}_{50}$ & $\mathbf{P}_{75}$ & $\begin{array}{c}E[R] \% \\
(\text { Mean) }\end{array}$ & $\begin{array}{c}E[R] \% \\
\left(P_{25}\right)\end{array}$ \\
\hline Granitic & 6 & 156 & 34 & 29 & 142 & 158 & 180 & 50 & 63 \\
Mafic & 14 & 143 & 42 & 29 & 113 & 147 & 167 & 56 & 69 \\
Metasediment & 26 & 130 & 60 & 46 & 83 & 148 & 173 & 64 & 71 \\
Metasediment* & 22 & 150 & 42 & 28 & 135 & 151 & 175 & 50 & 71 \\
Ore & 30 & 121 & 41 & 34 & 85 & 133 & 146 & 50 & 66 \\
Ore* & 26 & 130 & 35 & 27 & 108 & 135 & 147 & 50 & 64 \\
\hline
\end{tabular}

Note: * Low UCS values excluded

This method can also be applied to logging and rock mass classification data, provided that the data is arranged into equal length intervals. Table 6 summarises $Q^{\prime}$ data from an underground feasibility study, and includes the $P_{25}, P_{50} P_{75}$ values as well as the $E[R]$ at the mean and $P_{25}$ values. From this it can be seen that using the mean values does not satisfy the required reliability of $60-75 \%$ for a feasibility study, and that using the $P_{25}$ value provides the required reliability. It is worthwhile noting that even though the $C_{v}$ values are acceptable this does not translate into acceptable $E[R]$ values.

Table 6 Summary of $Q^{\prime}$ data for a narrow vein underground mine feasibility study

\begin{tabular}{lccccccccc}
\hline Rock unit & $\begin{array}{c}\text { Length } \\
(\mathbf{m})\end{array}$ & Mean & SD & $\begin{array}{c}\mathbf{C}_{\mathrm{v}} \\
(\mathbf{\%})\end{array}$ & $\mathbf{P}_{\mathbf{2 5}}$ & $\mathbf{P}_{\mathbf{5 0}}$ & $\mathbf{P}_{\mathbf{7 5}}$ & $\begin{array}{c}\mathrm{E}[\mathrm{R}] \% \\
(\text { Mean) }\end{array}$ & $\begin{array}{c}\mathrm{E}[\mathrm{R}] \% \\
\left(\mathbf{P}_{\mathbf{2 5}}\right)\end{array}$ \\
\hline Country rock & 4,131 & 65 & 2.6 & 4 & 40 & 70 & 150 & 45 & 63 \\
Vein & 283 & 20 & 4.1 & 20 & 10 & 15 & 55 & 57 & 75 \\
Vein - east wall & 235 & 28 & 3.2 & 11 & 15 & 40 & 80 & 55 & 73 \\
Vein - west wall & 244 & 39 & 2.9 & 7 & 18 & 45 & 80 & 58 & 81 \\
\hline
\end{tabular}

\section{$6 \quad$ Rating data reliability}

Whilst there are a range of qualitative and quantitative tools available for assessing the reliability of the geotechnical data and the geotechnical model, a scheme is required that brings this all together so that rating of the reliability can be assigned. Sullivan (2013) outlined a simple empirical system called the global slope performance index (GSPI) for assessing the likely performance and risks associated with excavated slopes. The GSPI comprises a simple algorithm that sums the scores from the separate rankings of five indices. The underlying philosophy and approach used is very similar to that outlined by Dunn and Laas (1999), who described a system developed to rate hazards associated with deep underground tabular mines in South Africa.

The approach and structure of these systems could be applied in developing a scheme for the assessment of geotechnical model and data reliability. Table 7 outlines a preliminary scheme for rating the reliability of a geotechnical model and its various components. This scheme requires significant further development and improvement in defining both qualitative and quantitative criteria to assess the various components. The rating scale also requires further development and is considered as only indicative at this stage. 
Table 7 Preliminary scheme for rating geotechnical model reliability

\begin{tabular}{|c|c|c|}
\hline Model & Element & $\begin{array}{c}\text { Rating } \\
\text { (\%) }\end{array}$ \\
\hline \multirow[t]{6}{*}{ Geological } & Regional interpretation of geology including stress field and seismicity & 30 \\
\hline & $\begin{array}{l}\text { Mine-scale mapping and targeted drilling to confirm geological } \\
\text { boundaries }\end{array}$ & 40 \\
\hline & Oriented drilling and logging (QA) - development of 3D model & 50 \\
\hline & $\begin{array}{l}\text { Increased density and spatial distribution of drilling and logging - } \\
\text { refinements of 3D model }\end{array}$ & 60 \\
\hline & Independent review of geology model and input data & 70 \\
\hline & Underground geology mapping used to refine and confirm 3D model & 80 \\
\hline \multirow{6}{*}{$\begin{array}{l}\text { Structural } \\
\text { (major) }\end{array}$} & Regional interpretation & 30 \\
\hline & Mine scale mapping and targeted drilling to confirm structures & 40 \\
\hline & Oriented drilling and structural characterisation - 3D model developed & 50 \\
\hline & $\begin{array}{l}\text { Increased density and spatial distribution of orientated drilling and } \\
\text { refinements of 3D model }\end{array}$ & 60 \\
\hline & Independent review of major structural model & 70 \\
\hline & Underground mapping used to refine and confirm 3D structural model & $>75$ \\
\hline \multirow{6}{*}{$\begin{array}{l}\text { Structural } \\
\text { (fabric) }\end{array}$} & Regional interpretation & 10 \\
\hline & Mine scale mapping and targeted drilling to confirm structures & 20 \\
\hline & $\begin{array}{l}\text { Oriented drilling and characterisation of structures and stereonets - } \\
\text { initial structural domains ( } 100 \text { measurements per set) }\end{array}$ & 40 \\
\hline & $\begin{array}{l}\text { Increased density and spatial distribution of oriented drilling; televiewer } \\
\text { surveys; characterisation of structures and stereonet refinements of } \\
\text { structural domains ( }>500 \text { measurements per set) }\end{array}$ & 60 \\
\hline & $\begin{array}{l}\text { Independent review of structural domains; statistics used to quantify } \\
\text { reliability }\end{array}$ & 70 \\
\hline & $\begin{array}{l}\text { Underground structural mapping used in refinement and confirmation of } \\
\text { structural domains }\end{array}$ & $>75$ \\
\hline \multirow[t]{6}{*}{ Hydrogeological } & Regional interpretation of groundwater level & 0 \\
\hline & $\begin{array}{l}\text { Airlift, pumping and packer testing to develop hydrogeological } \\
\text { parameters }\end{array}$ & 30 \\
\hline & $\begin{array}{l}\text { Increased density and spatial distribution of airlift, pumping and packer } \\
\text { testing; water quality and potential for ground support corrosion } \\
\text { assessed }\end{array}$ & 40 \\
\hline & $\begin{array}{l}\text { Hydrogeology spatial model - understanding of flow paths } \\
\text { underground }\end{array}$ & 50 \\
\hline & Independent review of hydrogeological model and input data & 60 \\
\hline & Ongoing data collection - refinement and confirmation of model & 75 \\
\hline
\end{tabular}




\begin{tabular}{|c|c|c|}
\hline Model & Element & $\begin{array}{l}\text { Rating } \\
\text { (\%) }\end{array}$ \\
\hline \multirow{5}{*}{$\begin{array}{l}\text { Rock mass } \\
\text { (intact) }\end{array}$} & Literature estimates for geological units & 30 \\
\hline & Field strength estimates from geological logging & 40 \\
\hline & $\begin{array}{l}\text { UCS and PLT of selected cores from geological and geotechnical drilling } \\
\text { (minimum of } 5 \text { samples per rock unit) }\end{array}$ & 60 \\
\hline & $\begin{array}{l}\text { Increased density and spatial distribution of UCS tests on selected cores } \\
\text { from geological and geotechnical drilling (small sampling theory used to } \\
\text { guide number of tests and reliability quantified using } C_{v} \text { and } E[R] \text { ) }\end{array}$ & 70 \\
\hline & Included in 3D geotechnical model and ongoing refinement & 80 \\
\hline \multirow{5}{*}{$\begin{array}{l}\text { Rock mass } \\
\text { (defect) }\end{array}$} & Literature estimates for geological units & 30 \\
\hline & Based on logging of joint characteristics & 40 \\
\hline & $\begin{array}{l}\text { Defect and saw-cut direct shear tests on selected cores (minimum of five } \\
\text { samples per rock unit) }\end{array}$ & 60 \\
\hline & $\begin{array}{l}\text { Increased density direct shear tests on cores from geological and } \\
\text { geotechnical drilling (small sampling theory used to guide number of } \\
\text { tests and reliability quantified using } C_{v} \text { and } E[R] \text { ) }\end{array}$ & 70 \\
\hline & $\begin{array}{l}\text { Ongoing refinement from underground characterisation and further } \\
\text { testing }\end{array}$ & 80 \\
\hline \multirow[t]{5}{*}{ Geotechnical } & Literature estimates for geological units & 30 \\
\hline & Geotechnical assessment of exploration cores (RQD and hardness) & 40 \\
\hline & $\begin{array}{l}\text { Geotechnical logging ( } Q \text { and } \mathrm{RMR} \text { ) of a representative proportion of } \\
\text { geology holes covering all major geological units - preliminary 3D } \\
\text { model }\end{array}$ & 60 \\
\hline & $\begin{array}{l}\text { Increased density and spatial distribution of geotechnical logging and } \\
\text { statistical quantification of geotechnical domains - 3D model refined; } \\
\left.\text { reliability quantified through } C_{v} \text { and } E[R]\right) \text {; stress measurements }\end{array}$ & 70 \\
\hline & $\begin{array}{l}\text { Underground mapping to confirm geotechnical domains and ongoing } \\
\text { refinement of model }\end{array}$ & 80 \\
\hline
\end{tabular}

\section{Conclusion}

This paper provides an overview of some of the issues associated with developing geotechnical models and deriving design input parameters that have reliabilities commensurate with the project's position within the project lifecycle.

Currently, there are several useful qualitative guidelines that relate the required level of geotechnical effort and data to the project lifecycle. In some cases, confidence levels have been specified, but there are difficulties in practically assessing confidence levels and reliability.

A number of methods that can be used to improve the reliability of geotechnical data, as well as methods that can be used to assess the reliability of geotechnical data, have been briefly explored. Examples were provided of the application of the latter group to laboratory testing and rock mass classification data from feasibility studies. These methods can be used to determine the confidence level and reliability of some components of the geotechnical model, such as strength properties and the rock mass quality. 
A preliminary scheme for rating the reliability of a geotechnical model and its various components has been proposed. This scheme requires significant further development and improvement in defining both qualitative and quantitative criteria to assess the various components. The rating scale is considered as only indicative at this stage and requires further development. It is envisaged that, as this scheme develops, it will allow the reliability of the geotechnical model and design input parameters to be assessed in a rigorous and consistent manner that can be directly related to industry guidelines.

\section{References}

Baecher, GB \& Christian, JT 2003, Reliability and statistics in geotechnical engineering, Wiley, London.

Barton, N, Lien, R \& Lunde, J 1974, 'Engineering classification of rock masses for the design of rock support', Rock Mechanics, vol. 6, pp. 189-236.

Beer, G \& Meek, JJ 1982, 'Design curves for roofs and hangingwalls in bedded rocks based on 'voussior' beam and plate solutions', Transactions of the Institute of Mining and Metallurgy, vol. 91, pp. A18-A22.

Bieniawski, ZT 1976, 'Rock mass classification in rock engineering', in ZT Bieniawski (ed.), Exploration for rock engineering: Proceedings of the Symposium on Exploration for Rock Engineering, A.A. Balkema, Lisse, pp. 97-106.

Bieniawski, ZT 1989, Engineering Rock Mass Classifications, John Wiley \& Sons, New York.

Carter, TG 2000, 'An update on the scaled span concept for dimensioning surface crown pillars for new or abandoned mine workings, Proceedings of the 4th North American Rock Mechanics Conference, American Rock Mechanics Association, Minneapolis, MN, pp. 465-472.

Cepuritis, P \& Villaescusa, E 2012, 'A reliability-based approach to open stope span design in underground mining', Proceedings of the 6th International Conference and Exhibition on Mass Mining (MassMin 2012), Canadian Institute of Mining, Metallurgy and Petroleum, Westmount, QC, CD-Rom only.

Department of Industry and Resources 1997, Geotechnical considerations in underground mines - guideline, viewed 11 May 2015, http://www.dmp.wa.gov.au/documents/Factsheets/MSH_G_GeotechnicalConsiderationsUGMines.pdf

Dunn, MJ 2013, 'Uncertainty in ground support design and implementation in underground mining', in Y Potvin (ed.), Proceedings of the Seventh International Symposium on Ground Support in Mining and Underground Construction (Ground Support 2013), Australian Centre for Geomechanics, Perth, pp. 345-358.

Dunn, MJ 2014, 'Geotechnical models and data confidence in mining geotechnical design', Proceedings of the Third Australasian Ground Control in Mining Conference (AusRock 2014), The Australasian Institute of Mining and Metallurgy, Melbourne pp. 105-112.

Dunn, MJ \& Laas, JJ 1999, 'The panel rating system - a risk management tool', in TO Hagan (ed.), Proceedings of the Second Southern African Rock Engineering Symposium, South African National Institute of Rock Engineering (SANIRE), Johannesburg, pp. 28-32.

Dunn, MJ, Basson, FR \& Parrott, TT 2011, ‘Geotechnical data - a strategic or tactical issue?', in Y Potvin (ed.), Proceedings of the Fourth International Seminar on Strategic versus Tactical Approaches in Mining, Australian Centre for Geomechanics, Perth, pp. 21-30.

Fillion, MH \& Hadjigeorgiou, J 2013, 'Reliability of strength estimates based on limited laboratory data', in P Dight (ed.), Proceedings of the 2013 International Symposium on Slope Stability in Open Pit Mining and Civil Engineering (Slope Stability 2013), Australian Centre for Geomechanics, Perth, pp. 163-176.

Gill, DE, Corthésy, R \& Leite, MH 2005, 'Determining the minimal number of specimens for laboratory testing of rock properties', Engineering Geology, vol. 78, pp. 29-51.

Goodman, RE \& Shi, G 1985, Block theory and its application in rock engineering, Prentice Hall, Upper Saddle River, NJ.

Hadjigeorgiou, J 2012, 'Where do the data come from?', in Y Potvin (ed.), Proceedings of the Sixth International Seminar on Deep and High Stress Mining (Deep Mining 2012), Australian Centre for Geomechanics, Perth, pp. 259-277.

Hadjigeorgiou, J \& Harrison, JP 2011, 'Uncertainty and sources of error in rock engineering', in Q Qian \& X Zhou (eds), Proceedings of the 12th ISRM International Congress on Rock Mechanics, Harmonising Rock Engineering and the Environment, CRC Press, Leiden, pp. 2063-2067.

Haile, A 2004, 'A reporting framework for geotechnical classification of mining projects', Bulletin of the Australasian Institute of Mining and Metallurgy, The Australasian Institute of Mining and Metallurgy, Melbourne, pp. 30-37.

Haines, A, Swart, A \& Kruger, A 2006, 'Proactively mitigating geotechnical risks in open pit and underground mining', Proceedings of the Second International Seminar on Strategic versus Tactical Approaches in Mining, Australian Centre for Geomechanics, Perth.

Harr, ME 1996, Reliability-based design in civil engineering, McGraw-Hill, Dover, NY.

Hedley, DGF \& Grant, F 1972, 'Stope-and-pillar design for the Elliot Lake Uranium Mines', Bulletin of the Canadian Institute of Mining and Metallurgy, vol. 65, no. 273, pp. 37-44.

Hoek, E \& Brown, ET 1988, 'The Hoek-Brown failure criterion - a 1988 update', in JC Curran (ed.), Proceedings of the 15th Canadian Rock Mechanics Symposium, Canadian Rock Mechanics Association, pp. 31-38.

Hoek, E \& Marinos, P 2000, 'GSI: a geologically friendly tool for rock mass strength estimation', Proceedings of the GeoEng 2000 Conference, pp. 1422-1442.

Hutchinson, DJ \& Falmagne, V 2000, 'Observational design of underground cablebolt support systems utilizing instrumentation', Bulletin of Engineering Geology and the Environment, vol. 58, no. 3, pp. 227-241. 
Joint Ore Reserves Committee 2004, JORC Code: Australasian Code for Reporting of Exploration Results, Mineral Resources and Ore Reserves, Joint Ore Reserves Committee, South Carlton.

Joint Ore Reserves Committee 2012, JORC Code: Australasian Code for Reporting of Exploration Results, Mineral Resources and Ore Reserves, Joint Ore Reserves Committee, South Carlton.

Lunder, P \& Pakalnis, RC 1997, 'Determination of the strength of hard rock pillars', Bulletin of the Canadian Institute of Mining, Metallurgy and Petroleum, vol. 90, no. 1013, pp. 51-55.

Mathews, KE, Hoek, E, Wyllie, DC \& Stewart, S 1981, Prediction of stable excavation spans for mining at depths below 1,000 metres in hard rock / Golder Associates, CANMET Library \& Documentation Services Division, Vancouver.

McCarthy, PL 1993, Objectives of feasibility studies, AMC Library.

McMahon, BK 1985, Geotechnical design in the face of uncertainty: EH Davis memorial lecture, Australian Geomechanics Society, Barton.

Peck, RB 1969, 'Advantages and limitations of the observational method in applied soil mechanics', Geotechnique, vol. 19, no. 2, pp. 171-187.

Potvin, Y 1988, 'Empirical open stope design in Canada' PhD thesis, University of British Columbia.

Read, J 2013, 'Data gathering, interpretation, reliability and geotechnical models', in P Dight (ed.), Proceedings of the 2013 International Symposium on Slope Stability in Open Pit Mining and Civil Engineering (Slope Stability 2013), Australian Centre for Geomechanics, Perth, pp. 81-89.

Read, J \& Stacey, P 2009, Guidelines for open pit slope design, CSIRO Publishing, Collingwood.

Steffen, OKH 1997, 'Planning of open pit mines on risk basis', Journal of The Southern African Institute of Mining and Metallurgy, vol. 2, pp. 47-56.

Sullivan, TD 2013, 'Global slope performance index', in P Dight (ed.), Proceedings of the 2013 International Symposium on Slope Stability in Open Pit Mining and Civil Engineering (Slope Stability 2013), Australian Centre for Geomechanics, Perth, pp. 55-80.

Thomas, RDH 2013, 'A statistical approach to account for elevated levels of uncertainty during geotechnical design', in P Dight (ed.), Proceedings of the 2013 International Symposium on Slope Stability in Open Pit Mining and Civil Engineering (Slope Stability 2013), Australian Centre for Geomechanics, Perth, pp. 325-335.

Wiles, TD 2006, 'Reliability of numerical modelling predictions', International Journal of Rock Mechanics and Mining Sciences, vol. 43, pp. 454-472.

Wiles, TD 2015, Map3D User's Manual, Map3D International Ltd, viewed 11 May 2015, http://www.map3D.com/ftp/ Map3D_Help.pdf 
